\title{
Karyotypic diversity and evolution of Loricariidae (Pisces, Siluriformes)
}

\author{
KF Kavalco ${ }^{1}$, R Pazza ${ }^{2}$, LAC Bertollo² and O Moreira-Filho ${ }^{2}$ \\ ${ }^{1}$ Departamento de Biologia/Genética, Instituto de Biociências, USP - Universidade de São Paulo, Rua do Matão, 277-Edifício André \\ Dreyfus, Cidade Universitária, ZIP 05508090, São Paulo, SP, Brazil; ${ }^{2}$ UFSCar-Universidade Federal de São Carlos, Departamento de \\ Genética e Evolução, Rodovia Washington Luís, km 235, ZIP 13565-905, São Carlos, SP, Brazil
}

\begin{abstract}
We present cytogenetic analyses of four fish species, belonging to four Loricariidae subfamilies: Neoplecostomus microps (Neoplecostominae) with $2 n=54$ chromosomes, Harttia loricariformis (Loricariinae) with $2 n=56$ chromosomes, Hypostomus affinis (Hypostominae) with $2 n=66$ chromosomes and Upsilodus sp. (Upsilodinae), with $2 n=96$ chromosomes. In addition to karyotypes, data on the location of $18 \mathrm{~s}$ rDNA sites are presented, derived from indirect (silver nitrate impregnation) and direct (FISH) methods. There is
\end{abstract}

only one pair of nucleolar organizing regions (NORs) per species, except in $H$. affinis. Diversity and NOR macrokaryotypic evolution in the species analyzed are discussed in relation to the evolution of the Loricariidae as a whole. In addition, a revision of the cytogenetic data available for this family is presented.

Heredity (2005) 94, 180-186. doi:10.1038/sj.hdy.6800595

Published online 24 November 2004

Keywords: karyotypic diversity; karyotypic evolution; Loricariidae fish; nucleolar organizer regions (NORs)

\section{Introduction}

The Serra da Bocaina region shelters the springs of the Paraitinga river, one of the main affluents of the Paraíba do Sul river, which is one of the most significant and important rivers of the East Brazilian drainage system. This area has suffered intense tectonic phenomena, facilitating the formation of population isolates, which constitute good models for cytogenetical and evolutionary studies. In the ichthyofauna of the Paraitinga river springs, small loricariid fishes belonging to the genera Neoplecostomus, Harttia, Hypostomus and Upsilodus are found.

The family Loricariidae contains about 600 species distributed into 70 genera, and is probably one of the families with the greatest taxonomic complexity among the Siluriformes (Isbrücker, 1980). The phylogenetic relationships of the family Loricariidae are relatively well defined, despite the great morphological diversity observed (Pina, 1998). Schaefer (1987) hypothesized that loricariids can be grouped in six subfamilies (Lithogeninae, Neoplecostominae, Hypoptopomatinae, Loricariinae, Ancistrinae and Hypostominae), constituting a monophyletic group. However, through the study of morphological characters (osteology and external and gastrointestinal anatomy), Armbruster (1997) proposed two new subfamilies, Hemipsilichthiinae and Upsilodinae, the latter being considered as the most basal among the loricariids, with only one monotypic genus, Upsilodus.

Correspondence: KF Kavalco, Departamento de Biologia/Genética, Instituto de Biociências, USP - Universidade de São Paulo, Rua do Matão, 277-Edifício André Dreyfus, Cidade Universitária, ZIP 05508090, São Paulo, SP, Brazil. E-mail: kavalco@biociencia.org

Received 30 October 2003; accepted 10 August 2004; published online 24 November 2004
Considering the number of species in this family, cytogenetic analyses are still scarce (Alves, 2000; Artoni and Bertollo, 2001), and nonexistent in the subfamilies Upsilodinae and Lithogeninae. The data available indicate that the smallest diploid number is $2 n=36$ chromosomes for Rineloricaria latirostris (GiulianoCaetano, 1998), and the highest is $2 n=80$ chromosomes in Hypostomus sp E (Artoni and Bertollo, 1996), showing the great numeric variability in this group. Additionally, there is also a general structural diversity, where members of the same nominal species may possess differentiated karyotypic formulae, as observed in Rineloricaria latirostris populations (Giuliano-Caetano, 1998). More detailed data on Loricariidae karyotypes are shown in Table 1.

Karyotypic variability analysis can be complemented by the chromosomal localization of specific genes, such as the nucleolar organizing regions (NORs). In fish, the location of the $45 \mathrm{~S}$ rDNA $(18 \mathrm{~S}+5.8 \mathrm{~S}+28 \mathrm{~S})$ is an important cytogenetic marker, with some groups having only one pair of NORs (Curimatidae, Anastomidae, Parodontidae, Prochilodontidae, Cichlidae), and others showing multiple NORs (Characidae, Lebiasinidae, Loricariidae, Erythrinidae and Callichthydae), including one located on a sex chromosome (Bertollo and Cavallaro, 1992; Born and Bertollo, 2000; Artoni and Bertollo, 2002). NOR localization can be carried out directly with fluorescent in situ hybridization (FISH) with specific probes, or indirectly with the use of silver nitrate (Ag-NOR). The latter detects the transcriptional activity of the ribosomal genes during the preceding interphase (Howell, 1977; Hubbel, 1985), since the silver binds to the nucleolar proteins and not directly to the rDNA (Miller et al, 1976).

The present work pursued the karyotypic characterization, in particular of the NORs of four Loricariidae 
Table 1 Cytogenetic data compilation for the family Loricariidae

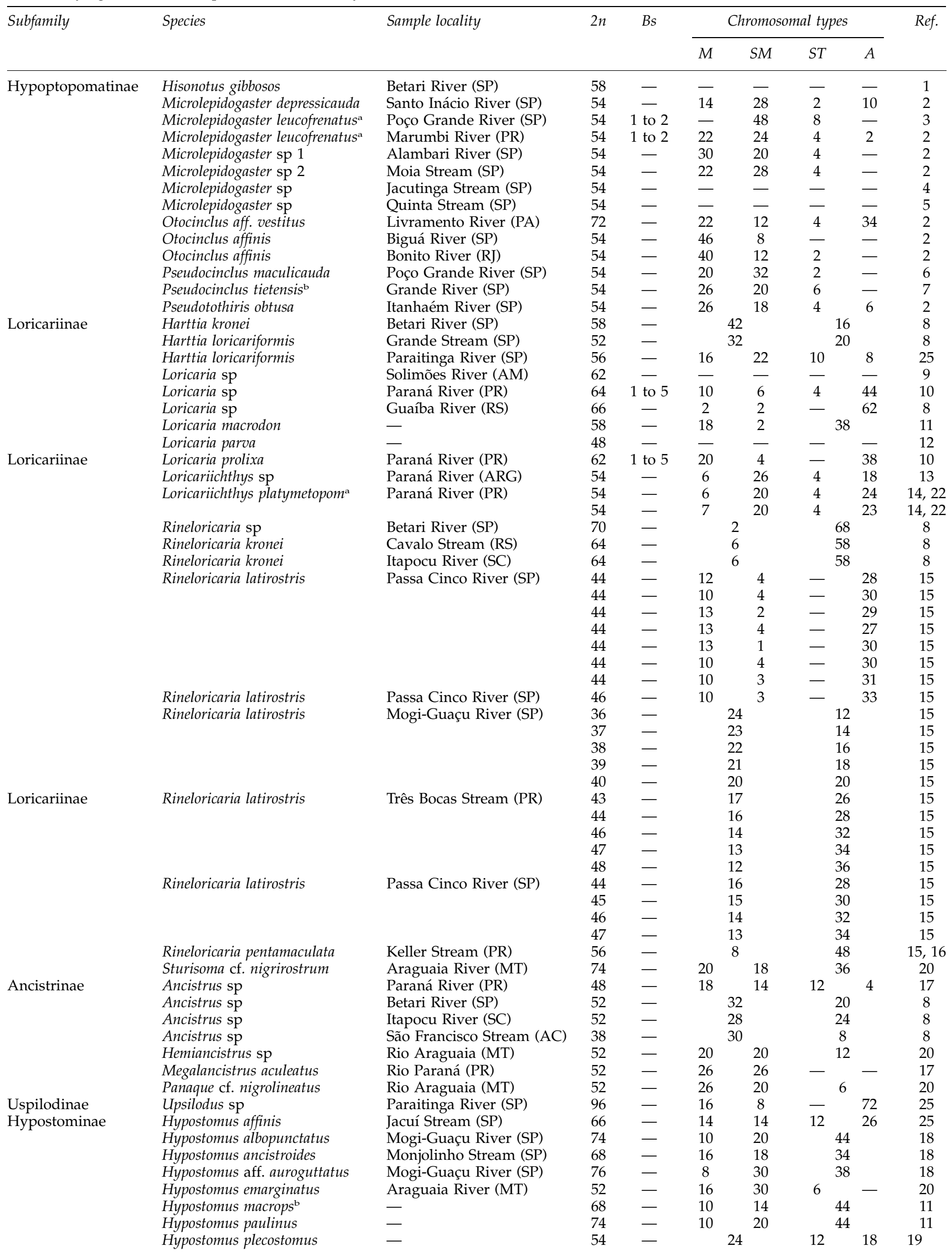


Table 1 Continued

\begin{tabular}{|c|c|c|c|c|c|c|c|c|c|}
\hline \multirow[t]{2}{*}{ Subfamily } & \multirow[t]{2}{*}{ Species } & \multirow[t]{2}{*}{ Sample locality } & \multirow[t]{2}{*}{$2 n$} & \multirow[t]{2}{*}{ Bs } & \multicolumn{4}{|c|}{ Chromosomal types } & \multirow[t]{2}{*}{ Ref. } \\
\hline & & & & & $M$ & $S M$ & ST & $A$ & \\
\hline & Hypostomus regani & Mogi-Guaçu River (SP) & 72 & - & 10 & 20 & & & 18 \\
\hline & Hypostomus sp A & Rincão Stream (SP) & 70 & - & 18 & 14 & & & 18 \\
\hline & Hypostomus sp B & Mogi-Guaçu River (SP) & 72 & - & 12 & 18 & & & 18 \\
\hline & Hypostomus sp B & Mogi-Guaçu River (SP) & 72 & - & 13 & 18 & & & 21 \\
\hline & Hypostomus sp $\mathrm{D}^{1}$ & Mogi-Guaçu River (SP) & 72 & - & 10 & 26 & & & 18 \\
\hline & Hypostomus sp $\mathrm{D}^{2}$ & Mogi-Guaçu River (SP) & 72 & - & 14 & 20 & & & 18 \\
\hline & Hypostomus sp E & Mogi-Guaçu River (SP) & 80 & - & 8 & 16 & & & 18 \\
\hline & Hypostomus sp F & São Francisco River (MG) & 76 & - & 10 & 16 & & & 17 \\
\hline & Hypostomus sp F & São Francisco River (MG) & 75 & - & 10 & 17 & & & 21 \\
\hline & Hypostomus sp Ga & Araguaia River (MT) & 64 & - & 14 & 24 & & & 24 \\
\hline & & & 64 & - & 15 & 24 & & & 24 \\
\hline & Hypostomus sp 1 & Quinta Stream (SP) & 72 & - & - & - & - & - & 5 \\
\hline & Hypostomus sp 2 & Alambari Stream (SP) & 68 & - & - & - & - & - & 5 \\
\hline & Hypostomus sp 3 & Paranapanema River (SP) & 66 & - & - & - & - & - & 5 \\
\hline \multirow{6}{*}{ Hypostominae } & Hypostomus sp 4 & Hortelã̃ Stream (SP) & 76 & - & - & - & - & - & 5 \\
\hline & Liposarcus anisitsi & Preto River (SP) & 52 & - & 16 & 24 & 8 & 4 & 23 \\
\hline & Liposarcus sp & Tietê River (SP) & 52 & - & - & - & - & - & 5 \\
\hline & Rhnielepsis aspera & Paraná River (PR) & 54 & - & 20 & 26 & 8 & - & 20 \\
\hline & Pogonopoma wertheimeri & Macuri River (BA) & 54 & - & 20 & 30 & 4 & - & 20 \\
\hline & Pterygoplichthys multiradiatus & Solimões River (AM) & 52 & - & - & - & - & - & 9 \\
\hline \multirow[t]{4}{*}{ Neoplecostominae } & Neoplecostomus microps & $\begin{array}{l}\text { Grande Stream (SP) } \\
\text { Pindamonhangaba City }\end{array}$ & 54 & - & \multicolumn{2}{|c|}{42} & \multicolumn{2}{|c|}{12} & 8 \\
\hline & Neoplecostomus microps & $\begin{array}{l}\text { Grande Stream (SP) } \\
\text { Campos do Jordão City }\end{array}$ & 54 & - & \multicolumn{2}{|c|}{42} & \multicolumn{2}{|c|}{12} & 8 \\
\hline & Neoplecostomus microps & Paraitinga River (SP) & 54 & - & 24 & 20 & 10 & - & 25 \\
\hline & Neoplecostomus paranensis & Hortelã Stream (SP) & 54 & - & \multicolumn{2}{|c|}{36} & \multicolumn{2}{|c|}{18} & 8 \\
\hline \multirow[t]{5}{*}{ Hemipsilichthiinae } & Isbrueckerichthys alipionis & Betari River (SP) & 54 & - & \multirow{2}{*}{\multicolumn{2}{|c|}{38}} & \multicolumn{2}{|c|}{16} & 8 \\
\hline & Kronichthys heylandi & Betari River (SP) & 54 & - & & & \multicolumn{2}{|c|}{4} & 8 \\
\hline & Hemipsilichthys splendens & São João River (SC) & 54 & - & \multicolumn{2}{|c|}{50} & \multirow{2}{*}{\multicolumn{2}{|c|}{$\begin{array}{c}4 \\
14\end{array}$}} & 8 \\
\hline & Hemipsilichthys steindachner & Cavalo Stream (SC) & 54 & - & \multicolumn{2}{|c|}{40} & & & 8 \\
\hline & Pareiorhina rudolphi & Grande Stream (SP) & 54 & - & \multicolumn{2}{|c|}{48} & \multicolumn{2}{|c|}{6} & 8 \\
\hline
\end{tabular}

${ }^{\mathrm{a}}$ Occurrence of a ZZ/ZW sex chromosome system reported. ${ }^{b}$ Occurrence of an $X X / X Y$ sex chromosome system reported. Bs $=$ presence of $B$ chromosomes; $\mathrm{M}=$ metacentric; $\mathrm{SM}=$ submetacentric; $\mathrm{ST}=$ subtelocentric; $\mathrm{A}=$ acrocentric; Ref. $=$ reference. $\mathrm{AC}=\mathrm{Acre} ; \mathrm{AM}=\mathrm{Amazonas}$; $\mathrm{BA}=$ Bahia; $\mathrm{MG}=$ Minas Gerais; $\mathrm{MT}=$ Mato Grosso; $\mathrm{PA}=$ Pará; $\mathrm{PR}=$ Paraná; $\mathrm{RJ}=$ Rio de Janeiro; $\mathrm{RS}=$ Rio $\mathrm{Grande}$ do Sul; $\mathrm{SC}=$ Santa Catarina; SP = São Paulo - Brazilian States; ARG = Argentina; 1 - Andreata et al (2000); 2 - Andreata et al (1994); 3 - Andreata et al (1993); 4 - Carvalho et al (1998); 5 - Fenerich (1998); 6 - Andreata (1991); 7 - Andreata et al (1992); 8 - Alves (2000); 9 - Della-Rosa et al (1980); 10 - Scavone and Júlio Jr (1994); 11 - Michelle et al (1977); 12 - Gyldenholm and Scheel (1971); 13 - Fenocchio (1993); 14 - Scavone (1993); 15 - Giuliano-Caetano (1998); 16 - Giuliano-Caetano et al (1999); 17 - Artoni (1996); 18 - Artoni and Bertollo (1996); 19 - Muramoto et al (1968); 20 - Artoni and Bertollo (2001); 21 - Artoni and Bertollo (1999); 22 - Scavone and Júlio Jr (1995); 23 - Artoni et al (1999); 24 - Artoni et al, 1998; 25 - Present paper.

species sampled from the Paraitinga river, with a discussion of probable events related to the karyotypic evolution of these fishes, in relation to their biological and cytogenetic characteristics.

\section{Materials and methods}

In all, 18 Neoplecostomus microps specimens (nine males and nine females), 22 Harttia loricariformis (eight males and 14 females) and three Upsilodus sp specimens (one male and two females) were collected from the Paraitinga river (S $22^{\circ} 52.225^{\prime} /$ Wo $44^{\circ} 51.041^{\prime}$ ), and two Hypostomus affinis specimens (males) from the Jacuí stream (S $23^{\circ} 02.436^{\prime} /$ Wo $44^{\circ} 56.103^{\prime}$ ), all belonging to the Paraíba do Sul river basin, São Paulo State (SP), Brazil. The samples were identified by the National Museum of Rio de Janeiro (Brazil), where they appear in the ichthyological collection under the OMNRJ REG 20020417 registration.

The mitotic chromosomes were obtained according to Bertollo et al (1978). The Ag-NOR impregnation followed the methodology of Howell and Black (1980). The localization of ribosomal cistrons was performed according to Pinkel et al (1986), by the use of FISH with a specific $18 S$ rDNA probe (kindly donated by Dr Terumi Hatanaka and Dr Pedro M Galetti Jr). The 185 rDNA probe was marked with biotinylated uridine (BdUTP) according to the protocol of the Nick Translation Bionik Labeling System Kit, Invitrogen ${ }^{\mathbb{R}}$. The signal amplification was performed using an FITC-avidin solution and a biotin-conjugated anti-avidin solution. The slides were mounted with $25 \mu \mathrm{l}$ Vectashield Mounting Medium antifade, $\operatorname{Vector}^{\mathbb{R}}$ with propidium iodide $(1.5 \mu \mathrm{g} / \mathrm{ml})$. The classification of the chromosomal types into metacentric, submetacentric, subtelocentric and acrocentric was based in their the arm ratios according to Levan et al (1964).

\section{Results}

A total of 534 metaphasic cells were analyzed for the four species, as follows: N. microps: $191 ; H$. loricariformis: 116 ; H. affinis: 148 and Upsilodus sp: 79. 
$N$. microps showed $2 n=54$ chromosomes, a $24 \mathrm{M}+20 \mathrm{SM}+10 \mathrm{ST}$ karyotypic formula and a fundamental number (FN) of 108 (Figure 1a). Only one NOR site was found using Ag-NOR and FISH (Figures $1 \mathrm{a}^{\prime}$ and $2 \mathrm{a}$, respectively), in an interstitial position in the long arm of the large submetacentric chromosome pair 14 .

$H$. loricariformis showed $2 n=56$ chromosomes, a $16 \mathrm{M}$ $+22 \mathrm{SM}+10 \mathrm{ST}+8 \mathrm{~A}$ karyotypic formula and a FN of 106 (Figure 1b). The NOR is also of the simple type (Figures $1 b^{\prime}$ and $2 b$ ), located in the terminal long-arm region of the large acrocentric chromosome pair 25 .

$H$. affinis showed a diploid number of $2 n=66$ chromosomes, with a $14 \mathrm{M}+14 \mathrm{SM}+12 \mathrm{ST}+26 \mathrm{~A}$ karyotypic formula and an FN of 106 (Figure 1c). Ag-NOR showed two to five NOR-bearing chromosomes (Figure $\left.1 \mathrm{c}^{\prime}\right)$, with a mode of 4 ; by in situ hybridization five $18 \mathrm{~S}$ rDNA sites were observed (Figure 2c), which corresponds to the maximum number of Ag-NORs obtained. They occur in the terminal region of the long arm of a metacentric and an acrocentric chromosome pair of medium size, in addition to the large acrocentric pair
21 , which presented a consistent size heteromorphism in the two males studied (Figure 1c).

Upsilodus sp possesses the highest diploid number ever observed in loricariids, $2 n=96$ chromosomes, with a $16 \mathrm{SM}+8 \mathrm{SM}+72 \mathrm{~A}$ karyotypic formula and an FN of 120 (Figure 1d). The Ag-NOR staining and 18S-FISH indicate the presence of a single NOR, located in the medium-sized metacentric chromosome pair 4 , in the terminal region of the long arm (Figures $1 \mathrm{~d}^{\prime}$ and $2 \mathrm{~d}$, respectively).

\section{Discussion}

Nearly 70 Loricariidae species have already been submitted to some cytogenetic study (Table 1). The diploid number of 54 chromosomes seems to be a plesiomorphic condition in this family. In Neoplecostominae and Hemipsilichthiinae, all the populations studied (four and five, respectively) have 54 chromosomes. Among 14 Hypoptopomatinae species, 12 possess this diploid number. For this reason, the subfamilies Neoplecostominae, Hemipsilichthiinae and Hypoptopomatinae are
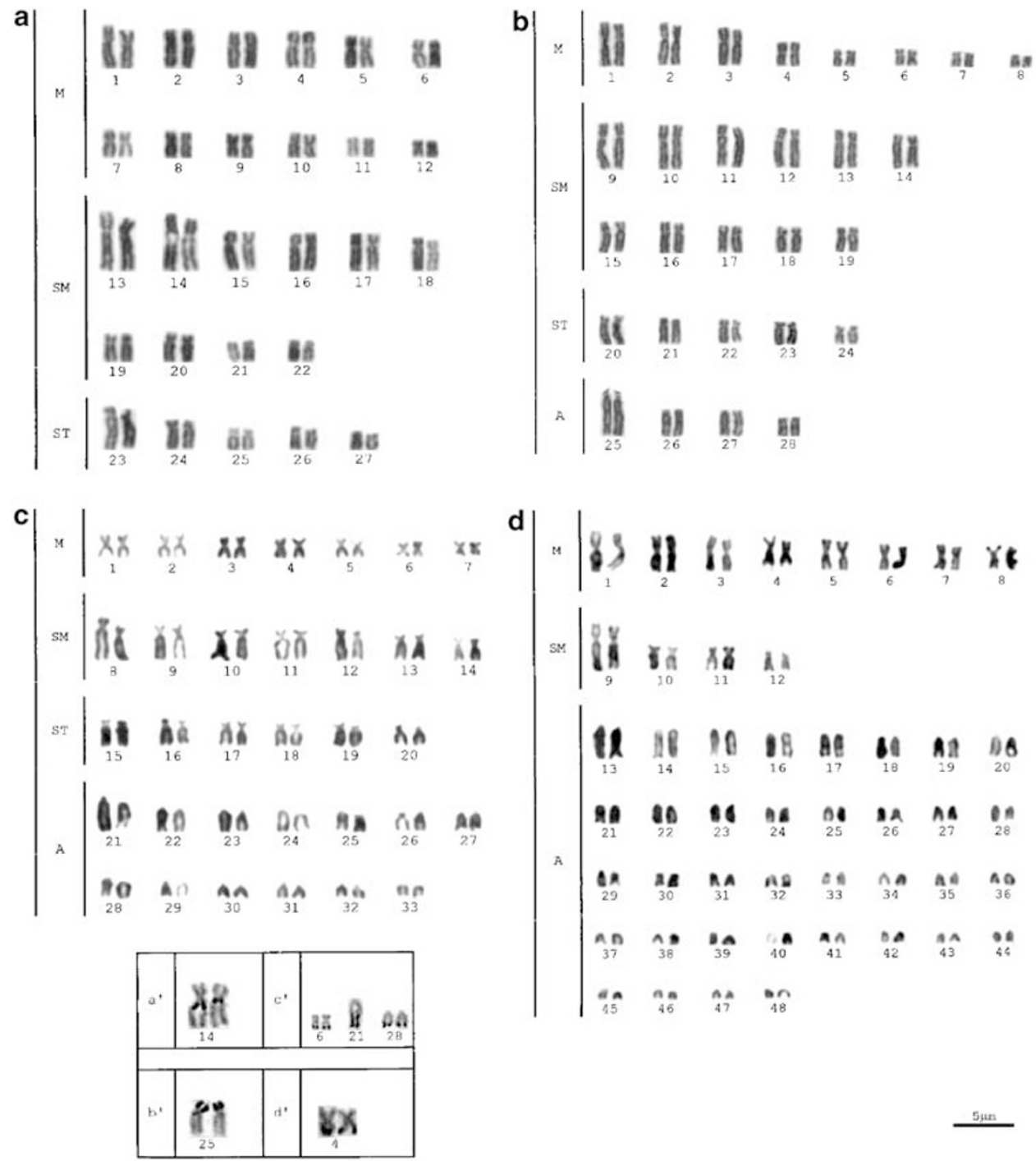

Figure 1 Giemsa-stained karyotypes of (a) N. microps; (b) H. loricariformis; (c) H. affinis and (d) Upsilodus sp. In detail, Ag-NORs of (a') N. microps; ( $\left.\mathbf{b}^{\prime}\right)$ H. loricariformis; $\left(\mathbf{c}^{\prime}\right)$ H. affinis; and $\left(\mathbf{d}^{\prime}\right)$ Upsilodus sp. 

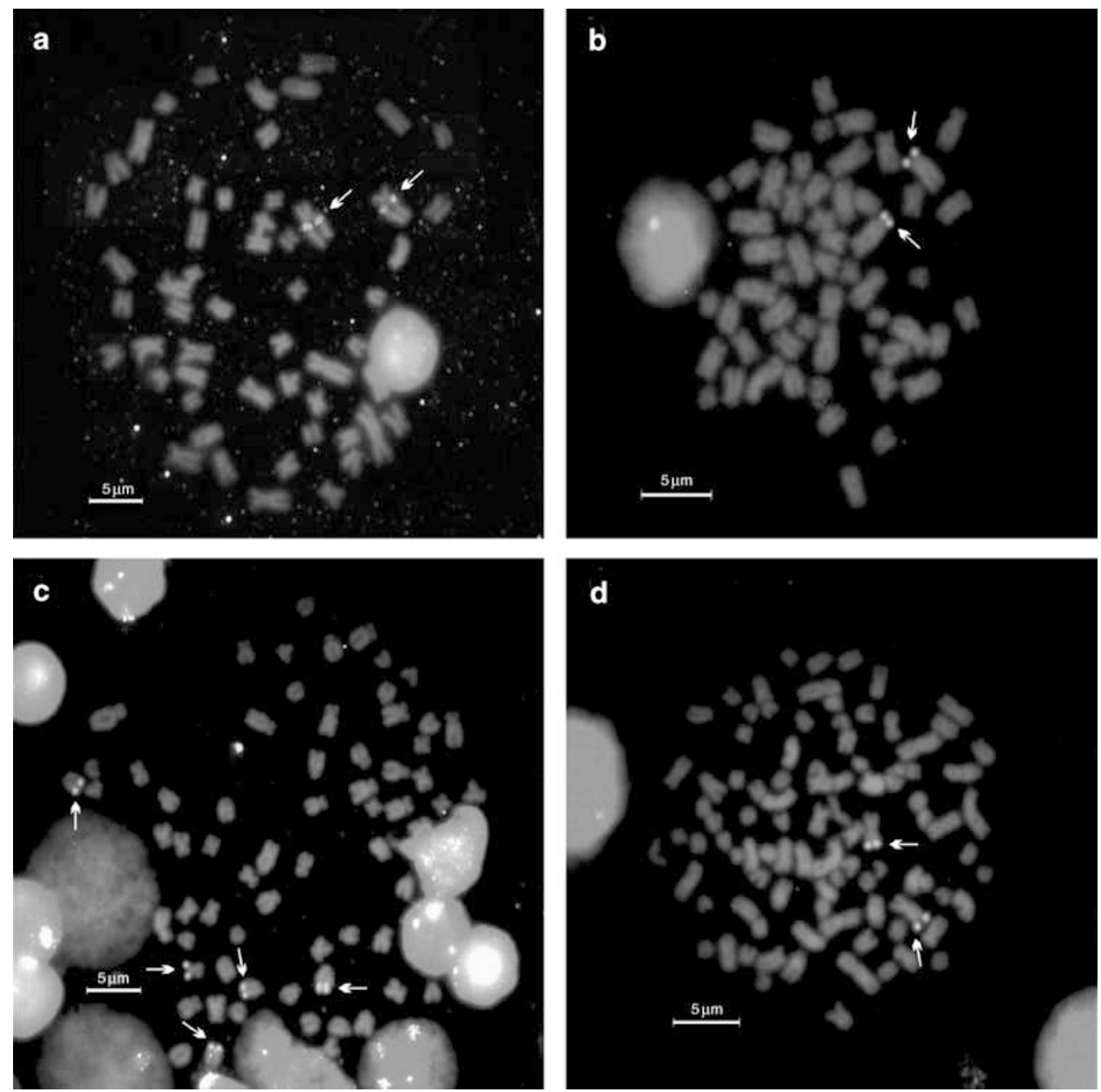

Figure 2 Fluorescent in situ hybridization with $18 \mathrm{~S}$ rDNA probe. The arrows indicate the sites in (a) N. microps; (b) H. loricariformis; (c) H. affinis and (d) Upsilodus sp.

considered basal, since they present a predominance of species with $2 n=54$ chromosomes (Alves, 2000). The karyotypes in these three subfamilies are made up of many biarmed chromosomes and, consequently, show high FNs.

It is interesting to observe that there are many acrocentric chromosomes (Andreata et al, 1994) in Otocinclus vestitus, which possesses the highest diploid number among the Hypoptopomatinae $(2 n=72)$. This seems to be one of the rare cases of karyotypic evolution by means of centric fissions in this subfamily, while the other species maintain the $2 n=54$ diploid number, and here rearrangements such as pericentric inversions seem to have a predominant role in the process of evolutionary divergence. Among the Neoplecostominae and Hemipsilichthiinae, this trend can also be observed in their karyotypic formulae (Table 1). N. microps, analyzed here, maintains this tendency with minor differentiations in the karyotype (Figure 1a).

Karyotypic evolution by means of centric fusions and centric fissions is, however, a common feature among other loricariids. This is seen in the subfamily Hypostominae, in particular the genus Hypostomus, where species with a lower diploid number have a higher number of biarmed chromosomes, and, in contrast, species with a higher diploid number have many uniarmed chromo- somes (Artoni and Bertollo, 1996, 2001). Considering $2 n=54$ chromosomes as the ancestral condition for loricariids, Artoni and Bertollo (2001) state that this second group represents more derived karyotypic forms. In addition to their very variable diploid numbers and chromosomal types, the genus Hypostomus also shows karyotypic differentiation within species, as is observed among H. affinis populations (Carneiro et al, 1998 and the present study), where the diploid number is maintained but the chromosomal formula is variable (Figure 1c). The available data for the genera Hypostomus, Liposarcus, Rhinelepis, Pognopoma and Pterygoplichthys (Table 1) indicate that Robertsonian rearrangements, as well as pericentric inversions, were the main rearrangements related with the karyotypic diversification of the Hypostominae. On the other hand, this chromosomal diversity may also corroborate a probable polyphyletic origin of the Hypostominae species, as proposed by Schaefer (1987) on the basis of morphological studies.

Data on chromosomal evolution in the subfamily Ancistrinae are still very scarce, since this is a littlestudied group. The diploid number comprises $50 \pm 2$ chromosomes, with a predominance of $2 n=52$ and the constant presence of meta-, sub-meta, sub-telo and acrocentric chromosomes (Table 1). Ancistrus sp shows only $2 n=38$ chromosomes (Alves, 2000) and Robertsonian 
rearrangements appear to have raised the number of metacentric chromosomes and lowered the diploid number.

In the subfamily Loricariinae, both centric fissions, centric fusions and pericentric inversions emerge again as common karyotypic rearrangements. In Rineloricaria latirostris, for example, a Robertsonian polymorphism was observed, with a variation of $2 n=36$ to $2 n=48$ chromosomes (Giuliano-Caetano, 1998). The great variety of diploid numbers among species of Loricariinae, in addition to the small number of species analyzed, makes it difficult to discern an evolutionary trend in this group. There are, however, a dozen species in this subfamily that have $2 n=54 \pm 2$ chromosomes, pointing to the same karyotypic trend observed in Hypoptopomatinae, Neoplecostominae and Hemipsilichthiinae.

$H$. loricariformis, the Loricariinae representative in the present study, showed a karyotypic difference from the other population of the same species from the Grande stream (Alves, 2000), also belonging to the Paraíba do Sul basin. This differentiation includes the diploid number $(2 n=52$ vs $2 n=56$ in the present work), the karyotypic formula, symmetry (since the karyotype of the population analyzed here shows itself more asymmetrical) and NOR localization. H. loricariformis from the Paraitinga river (Figure $1 b$ ) has a karyotype more similar to $H$. kronei (Table 1), showing a greater amount of biarmed chromosomes than H. loricariformis from the Grande stream. Thus, pericentric inversions seem to have played an important role in this genus, modifying its chromosome types. In this way, species with a certain 'karyotypic plasticity' are found among the Loricariidae. The sedentary habit of some species may contribute to these differentiations, as isolated populations are formed.

Upsilodinae was recently considered as the most basal Loricariidae subfamily (Armbruster, 1997), possessing only one species, Upsilodus victori. However, Lima (1997) considers that specimens derived from the Paraibuna river (São Paulo State, Brazil) may constitute another species, due to marked differences in morphological characters. These differences were also observed in the four specimens analyzed in the present study from the Paraitinga river, where an adult male showed a conspicuous sex dimorphism. Upsilodus $\mathrm{sp}$ has the highest diploid number among Loricariidae $(2 n=96)$, with a karyotype made up of many acrocentric chromosomes (Figure 2d), again indicating centric fission events.

The NORs in loricariids show varied phenotypes. A trend for the maintenance of the plesiomorphic condition is observed, that is, a single NOR pair located at a terminal position on the chromosomes (Oliveira and Gosztonyi, 2000). Artoni (1996) proposed that the ancestral NOR phenotype for Loricariidae is a terminal site on the long arm of a large metacentric chromosome, since this feature is found both in Hypostominae and Hypoptopomatinae. Nonetheless, there are groups that also have multiple NOR sites, as in many Hypostominae species (Artoni and Bertollo, 2001).

Despite its specificity in the diploid number, Upsilodus sp maintains a single NOR pair in a terminal position on a large metacentric pair (Figures $1 d^{\prime}$ and $2 d$ ). The occurrence of this NOR phenotype in Upsilodus $\mathrm{sp}$ corroborates Artoni's (1996) proposition. So, besides basal chromosome features, Upsilodus sp shows an autapomorphy in relation to its elevated diploid number, with many acrocentric chromosomes.

Other Loricariidae fishes with high diploid numbers, such as several Hypostominae species (Table 1), show variable NOR phenotypes (Artoni and Bertollo, 2001), as was also observed in $H$. affinis in the present study, which possesses five rDNA sites (Figures $1 c^{\prime}$ and 2c). The absence of a site in one homologue of the first acrocentric pair (pair 21) could be due to unequal crossovers, which would explain the size heteromorphism of this chromosome pair (Figure 1c). No homozygosity was detected for this site, possibly due to the sample size analyzed.

It is estimated that nearly $25 \%$ of the Loricariidae species show interstitial NORs (Alves, 2000). N. microps has this NOR state (Figures $1 \mathrm{a}^{\prime}$ and $2 \mathrm{a}$ ), also observed in other Neoplecostominae species. In addition, Hypoptopomatinae and Hemipsilichthiinae also show species with interstitial NORs. Therefore, the event that produced this phenotype may have occurred in a common ancestor for these three subfamilies, and, if so, would constitute a synapomorphic feature. However, among Hypoptopomatinae, only about $43 \%$ of the species have this phenotype (Alves, 2000), the remainder showing terminal NORs, which impairs a precise evolutionary interpretation for this character, without ruling out the occurrence of homoplasies.

In Loricariinae, the most frequent NOR phenotype is also a terminal location, as observed in $H$. loricariformis (Figures $1 b^{\prime}$ and $2 b$ ). The remaining Harttia species analyzed, however, show interstitial NORs (Alves, 2000), indicating a nonshared synapomorphy with H. loricariformis.

In conclusion, the data available indicate different evolutionary pathways within subfamilies as well as between different Loricariidae subfamilies. Some chromosomal features, such as diploid number and NOR phenotypes, may in fact be shared by different groups, indicating a common ancestry, or may be seen as derived and specific characters. The same occurs with heteromorphic sex chromosomes in this family. Male and female heterogamety, such as the $X X / X Y$ and $Z Z / Z W$ systems, have already been identified for some Loricariidae (Michelle et al, 1977; Andreata et al, 1992, 1993, 1994; Scavone and Júlio Jr, 1995; Artoni et al, 1998), but represent isolated events in this group.

\section{Acknowledgements}

We thank Paulo A Buckup, PhD, for taxonomic identification of the species analyzed. This work was supported by FAPESP (Proc. 01/00713-0 and 01/05185-5) and CNPq.

\section{References}

Alves AL (2000). Análise da evolução dos gêneros da subfamília Hemipsilichthiinae (Ostariophysi, Siluriformes, Loricariidae) com base em caracteres cromossômicos e de DNA mitocondrial. MSc Thesis, Universidade Estadual Paulista. 129pp.

Andreata AA (1991). Estudos citogenéticos na subfamília Hypoptopomatinae (Pisces, Siluriformes, Loricariidae). MSc Thesis, Universidade de São Paulo. 171pp.

Andreata AA, Almeida-Toledo LF, Oliveira C, Toledo-Filho SA (1992). Chromosome studies in Hypoptopomatinae (Pisces, Siluriformes, Loricariinae) I: XX/XY sex chromosome heteromorphism in Pseudotocinclus tietensis. Cytologia 57: 369-372. 
Andreata AA, Almeida-Toledo LF, Oliveira C, Toledo-Filho SA (1993). Chromosome studies in Hypoptopomatinae (Pisces, Siluriformes, Loricariinae) II: ZZ/ZW sex-chromosome system, B chromosomes, and constitutive heterochromatin differentiation in Microlepdogaster leucofrenatus. Cytogenet Cell Genet 63: 215-220.

Andreata AA, Almeida-Toledo LF, Oliveira C, Toledo-Filho SA (1994). Chromosome studies in Hypoptopomatinae (Pisces, Siluriformes, Loricariinae) III: Analysis of seven species. Caryologia 47: 27-37.

Andreata AA, Alves AL, Foresti F, Oliveira C (2000). Hisonotus gibbosos (Teleostei, Loricariidae) segundo Hypoptopomatíneo com número diplóide diferente de 54 cromossomos. Genet Mol Biol 23(Suppl.): 57.

Armbruster JW (1997). Phylogenetic relationships of the sucker-mouth armored catfishes (Loricariidae) with particular emphasis on the Ancistrinae, Hypostominae, and Neoplecostominae. PhD Thesis, University of Illinois, 409pp.

Artoni RF (1996). Estudos citogenéticos na família Loricariidae, com ênfase no gênero Hypostomus Lacépède (1803) (Pisces, Siluriformes). MSc Thesis, Universidade Federal de São Carlos. 162pp.

Artoni RF, Bertollo LAC (1996). Cytogenetic studies on Hypostominae (Pisces, Siluriformes, Loricariidae). Considerations on karyotype evolution in the genus Hypostomus. Caryologia 49: 81-90.

Artoni RF, Bertollo LAC (1999). Nature and distribution of constitutive heterochromatin in fishes, genus Hypostomus (Loricariidae). Genetica 106: 209-214.

Artoni RF, Bertollo LAC (2001). Trends in the karyotype evolution of Loricariidae fish (Siluriformes). Hereditas $\mathbf{1 3 4}$ 201-210.

Artoni RF, Bertollo LAC (2002). Evolutionary aspects of the ZZ/ ZW sex chromosome system in the Characidae fish, genus Triportheus. A monophyletic state and NOR location on the W chromosome. Heredity 89: 15-19.

Artoni RF, Molina WF, Bertollo LAC, Galetti Jr PM (1999). Heterochromatin analysis in the fish species Liposarcus anisitsi (Siluriformes) and Leporinus elongatus (Characiformes). Genet Mol Biol 22: 1-6.

Artoni RF, Venere PC, Bertollo LAC (1998). A heteromorphic $\mathrm{ZZ/ZW} \mathrm{sex} \mathrm{chromosome} \mathrm{system} \mathrm{in} \mathrm{fish,} \mathrm{genus} \mathrm{Hypostomus}$ (Loricariidae). Cytologia 63: 421-425.

Bertollo LAC, Cavallaro ZI (1992). A highly differentiated ZZ/ ZW sex chromosome system in a Characidae fish Triportheus guentheri. Cytogenet Cell Genet 60: 60-63.

Bertollo LAC, Takahashi CS, Moreira-Filho O (1978). Cytotaxonomic considerations on Hoplias lacerdae (Pisces, Erythrinidae). Braz J Genet 1: 103-120.

Born GG, Bertollo LAC (2000). An XX/XY sex chromosome system in a fish species, Hoplias malabaricus, with a polymorphic NOR-bearing $\mathrm{X}$ chromosome. Chromosome Res 8: 111-118.

Carneiro ASP, Pauls E, Oliveira ASS, Silva LP, Vieira WS (1998). Projeto Managé: Estudos citogenéticos de Harttia sp. e Loricariichthys sp. (Pisces, Loricariidae) da bacia hidrográfica do rio Itabopoana (MG/ES/RJ). In: VII Simpósio de Citogenética e Genética de Peixes. Londrina, PR p B11.

Carvalho ML, Oliveira C, Foresti F (1998). Nuclear content of thirty species of Neotropical fishes. Genet Mol Biol 21: 47-54.

Della-Rosa VA, Bertollo LAC, Ferrari I, Takahashi CS, MoreiraFilho O, Foresti F (1980). Estudos citogenéticos em peixes da Amazônia II: Ordem Siluriformes. Ciência e Cultura 32(Suppl): 735.

Fenerich PC (1998). Estudo de conteúdo de DNA nuclear em células de peixes da ordem Siluriformes (Pisces,
Ostariophysi), da região de Botucatu, SP. MSc Thesis, Universidade Estadual Paulista. 127pp.

Fenocchio AS (1993). Cromossomos supranumerários no gênero Rhamdia (Pisces). Caracterização cromossômica e considerações sobre a evolução cariotípica nos Siluroidei. PhD Thesis, Universidade de São Paulo. 122pp.

Giuliano-Caetano L (1998). Polimorfismo cromossômico Robertsoniano em populações de Rineloricaria latirostris (Pisces, Loricariinae). PhD Thesis, Universidade Federal de São Carlos. 78pp.

Giuliano-Caetano L, Moreira-Filho O, Bertollo LAC (1999). Estudos citogenéticos em Rineloriaria pentamaculata (Langeani e Araújo, 1994). Genet Mol Biol 22(Suppl): 192.

Gyldenholm AO, Scheel JJ (1971). Chromosome numbers of fishes I. I Fish Biol 3: 479-486.

Howell WM (1977). Visualization of ribosomal gene activity: silver stain proteins associated with RNA transcribed from oocyte chromosomes. Chromosoma 62: 361-367.

Howell WM, Black DA (1980). Controlled silver-staining of nucleolus organizer regions with a protective colloidal developer: a 1-step method. Experientia 36: 1014-1015.

Hubbel HR (1985). Silver staining as an indicator of active ribosomal genes. Stain Technol 60: 285-294.

Isbrücker IJH (1980). Classification and catalogue of the mailed Loricariidae (Pisces, Siluriformes). Verslagen Techn Gegevens 22: 1-181.

Levan A, Fredga K, Sandberg AA (1964). Nomenclature for centromeric position on chromosomes. Hereditas 52: 201-220.

Lima RS (1997). Ictiofauna do alto curso do Rio Paraíba do Sul. MSc Thesis, Universidade de São Paulo. 221pp.

Michelle JL, Takahashi CS, Ferrari I (1977). Karyotypic study of some species of the family Loricariidae (Pisces). Cytologia 42: 539-546.

Miller DA, Dev VG, Tantravahi R, Miller OJ (1976). Suppression of human nucleolus organizer in mouse-human somatic hybrid cells. Exp Cell Res 101: 235-243.

Muramoto J, Ohno S, Atkin NB (1968). On the diploid state of the fish order Ostariophysi. Chromosoma 24: 59-66.

Oliveira C, Gosztonyi AE (2000). A cytogenetic study of Diplomystes mesembrinus (Teleostei, Siluriformes, Diplomystidae) with a discussion of chromosome evolution in Siluriformes. Caryologia 53: 31-37.

Pina MCC (1998). Phylogenetic relationships of neotropical Siluriformes (Teleostei, Ostariophysi): historical overview and synthesis of hypotheses. In: Malabarba LR, Reis RE, Vari RP, Lucena ZMS, Lucena CAS (eds) Phylogeny and Classification of Neotropical Fishes. EDIPUCRS: Porto Alegre, pp 279-330, 603pp.

Pinkel D, Straume T, Gray JW (1986). Cytogenetic analysis using quantitative, high-sensitivity, fluorescence hybridization. Proc Natl Acad Sci USA 83: 2934-2938.

Scavone MDP (1993). Análise citogenética de espécies dos gêneros Loricaria e Loricariichthys (Loricariidae, Siluriformes) da bacia do rio Paraná. MSc Thesis, Universidade Estadual de Maringa. 82pp.

Scavone MDP, Júlio Jr HF (1995). Cytogenetics analysis and heterochromatin distribution in $\mathrm{ZZ} / \mathrm{ZW}$ sex chromosomes of the mailed catfish Loricariichthys platymetopon (Loricariidae: Siluriformes). Braz J Genet 18: 31-35.

Scavone MDP, Júlio Jr HF (1994). Cytogenetic analysis and probable supernumerary chromosomes of Loricaria prolixa and Loricaria sp. females (Loricariidae - Siluriformes) from the Paraná river basin. Rev Ictiol 2/3: 41-47.

Schaefer SA (1987). Osteology of Hypostomus plecostomus (Linnaeus), with a phylogenetic analysis of the loricariid subfamilies (Pisces, Siluroidei). Contr Sci Nat Hist Mus Los Angeles County 394: 1-31. 